\title{
Assessment of Changes in the Structure of Zooplankton Communities to Infer Water Quality of the Caspian Sea
}

\author{
Elena Krupa ${ }^{1,2}$ \\ 1 Kazakh Agency of Applied Ecology, Amangeldy 70a, Almaty 050012, Kazakhstan; elena_krupa@mail.ru \\ 2 Institute of Zoology, al Faraby 93, Almaty 050060, Kazakhstan
}

Received: 5 July 2019; Accepted: 24 July 2019; Published: 26 July 2019

\begin{abstract}
The work aimed to study the structural variables of zooplankton to assess the water quality of the Caspian Sea. Studies of zooplankton were conducted in the spring and summer of 2008 and 2010. Abundance, biomass, an average individual mass of a specimen, Shannon Bi, Shannon Ab, $\Delta$-Shannon indices, and Clarke's W-statistic were calculated for zooplankton. Quantitative variables of zooplankton were the highest in the Northeastern and Northern Caspian, decreasing towards the Middle Caspian. In the Northeastern and Northern Caspian from spring to summer, the number of zooplankton, and the values of Shannon $\mathrm{Bi}$ and Shannon $\mathrm{Ab}$ indices decreased; the values of $\Delta$-Shannon and Clarke's W-statistic increased. In the Middle Caspian, the biomass of the community increased; the values of $\Delta$-Shannon and Clarke's W-statistic decreased. From spring to summer, the value of an average individual mass of a specimen decreased over the entire surveyed area. The jellyfish Blackfordia virginica and Moerisia pallasi significantly influenced the size structure of the holoplankton. Seasonal dynamics of structural variables of zooplankton as well as changes in water transparency showed that water quality improved from spring to summer in the shallow northern and northeastern areas of the sea, and decreased in the deep-water Middle Caspian.
\end{abstract}

Keywords: bioindication; Caspian Sea; Clarke's W-statistic; water quality; structure; zooplankton

\section{Introduction}

Global warming, along with an increased anthropogenic load, is the main predictor of long-term changes in marine ecosystems [1-3]. The Caspian Sea, the largest inland water body, is polluted by precipitation, shipping traffic, oil operations, and emergency oil spills [4]. The main pollutants are petroleum hydrocarbons [5], heavy metals [6,7], residual concentrations of organochlorine pesticides [8], and organic matter [9].

Along with climate change [10], and the intensity of pollution $[8,11,12]$, the ecological status of the Caspian Sea depends on cyclical changes in water level [13]. The change in the flow of the rivers is one of the reasons for the inter-annual dynamics of the hydrological regime of the Caspian. The regressive hydrological phase began in 1996 and continues to the present [14]. According to [8,11,14], a decrease in river flow is one of the reasons for reducing pollution of the Caspian Sea in recent decades. The significant contribution of river flow to the overall level of contamination of the Caspian Sea [9] reflects the spatial distribution of pollutants in its waters. The highest concentrations of the main pollutants are recorded in the inflow zone of the rivers [15].

For an objective assessment of the water quality of aquatic ecosystems, it is necessary to take into account the whole complex of abiotic factors, which is a challenging task. Bioindication methods provide an integrated assessment of the water quality of a water body since the structure of biological communities is influenced by both natural and anthropogenic factors [16]. 
Planktonic algae as primary producers of organic matter have a high indicator significance for the assessment of organic [17] and toxic pollution of aquatic ecosystems [18]. Along with abiotic factors, the species composition and quantitative variables of phytoplankton determine the structure of the communities of the upper trophic levels-zooplankton [19] and macrozoobenthos [20]. Plankton and benthic invertebrates, in turn, consume algae and affect the structure of phytoplankton communities. Thus, there is a close relationship between phytoplankton, zooplankton, and macrozoobenthos, which is formed under the influence of a complex of natural and anthropogenic factors. This makes it possible to use any community for bioindication.

Bioindication is widely used in assessing the ecological state of inland waters. The assessment of the level of organic pollution of water bodies is carried out based on the analysis of the species composition [21,22], and quantitative and structural variables of the communities [22-26]. A positive relationship with the total phosphorus content was established for such variables as the amount of chlorophyll "a" [27], the number of species of crustaceans and rotifers; percentage share of cyclopoid biomass in total biomass of Crustacea, the abundance of Rotifera, the biomass of Cyclopoida, and the ratio of the cyclopoid biomass to the biomass of Cladocera [22,28]. A characteristic feature of the eutrophication of water bodies is a decrease in an average individual mass of a specimen in zooplankton communities $[22,25,26,29]$ or an average cell volume in phytoplankton communities [30,31].

The rank distribution of species in communities described by the ABC-Method (Abundance and Biomass Comparing) [32] is closely related to the size variables of communities [23,24]. As a rule, negative $\mathrm{W}$ values of Clark statistics [33] are recorded in communities consisting of small-sized species $[23,25,26,34]$. Under the influence of external conditions, dimensional variables of communities change earlier than the species composition $[35,36]$, which causes a high indicator significance of dimensional variables in the assessment of the ecological status of water bodies.

Bioindication methods were used in assessing the level of organic and toxic pollution of the Red, Mediterranean, Northern [37], and Azov seas [38]. Until now, the assessment of the ecological state of the Caspian Sea has been carried out mainly based on chemical analysis data $[4,39]$. The monographs $[14,15,40]$ summarized information on the content of the main pollutants in the water and soils of the Northern and Northeastern Caspian Sea for the period from 1996 to 2016. It was shown that the level of toxic pollution of the sea has slightly decreased; the average concentrations of organic nitrogen increased, while the content of organic phosphorus decreased [40]. Obviously, it is difficult to assess the integrated quality of seawater, when a broad set of environment variables is taken into account in chemical monitoring. This problem can be solved by using biological indicators because the structure of biological communities is formed under the influence of the whole complex of natural and anthropogenic factors.

The purpose of this work was to study the spatial and seasonal dynamics of structural variables of zooplankton communities to assess the water quality of the Northern, Northeastern, and Middle Caspian Sea.

\section{Materials and Methods}

\subsection{Description of Study Area}

The area of the Caspian Sea, the largest inland water body, is $378,400 \mathrm{~km}^{2}$ [41]. Based on the morphological structure and physiographic conditions, the sea can be divided into three parts: The Northern, Middle, and Southern Caspian. The Mangyshlak Threshold, stretched from Cape Tiub-Karagan to Chechen Island, separates the Northern and Middle Caspian (Figure 1). Within the Northern Caspian, its shallowest part is sometimes distinguished-the Northeastern Caspian. The Apsheron Threshold divides the Middle and Southern Caspian. Depths increase from north to south. The greatest depths of the northern, middle, and southern parts of the sea are 25, 788, and $1025 \mathrm{~m}$, respectively. The average depth of the sea reaches $208 \mathrm{~m}$. 


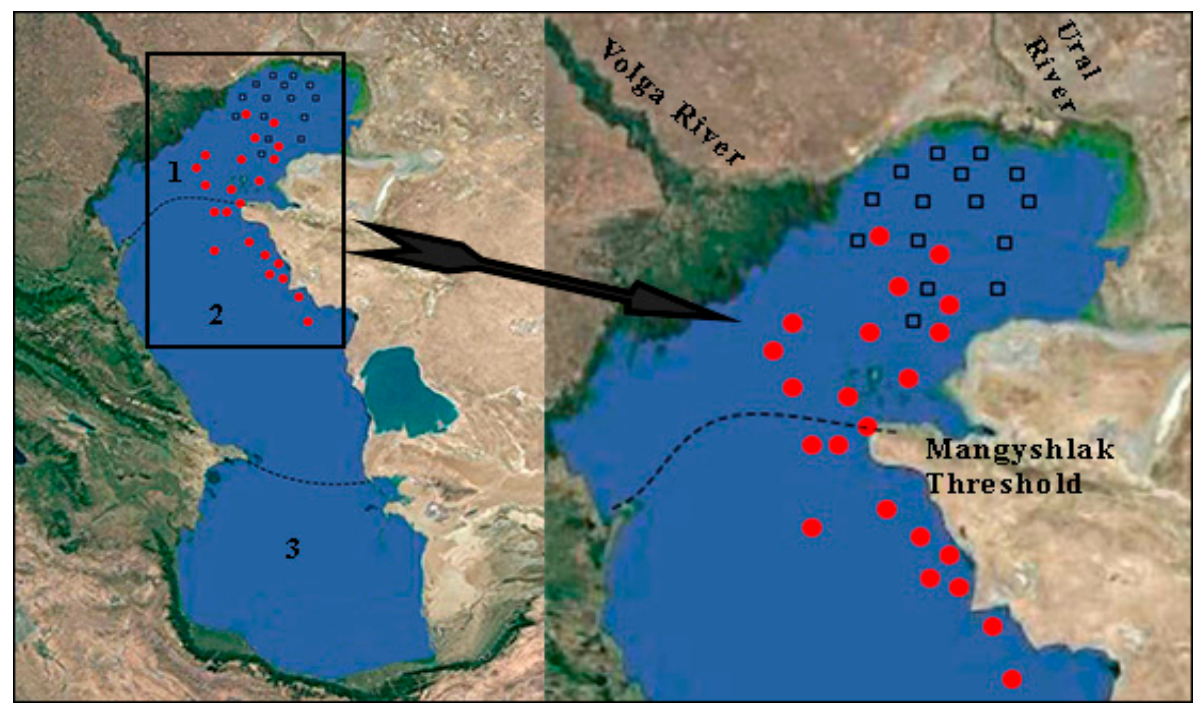

Figure 1. Map of sampling stations in the Kazakhstan sector of the Caspian Sea in 2008 and 2010. Dotted lines are the boundaries between the Northern (1), Middle (2), and Southern (3) Caspian. Circles are the stations for material selection in 2008, squares-the stations for material selection in 2010.

A total of 130 rivers flow into the Caspian Sea. The Volga, Ural, Terek, Sulak, and Emba rivers account for $88 \%-90 \%$ of the annual flow. The salinity of water varies from $0.05 \%$ o near the mouth of the Volga River to $11 \%$ o- $13 \%$ in the southeast of the water area. The maximum water temperature is observed in August and reaches $24-26{ }^{\circ} \mathrm{C}$, and in the southern regions $28^{\circ} \mathrm{C}$. Surface water sometimes warms up to $32{ }^{\circ} \mathrm{C}$ in shallow bays in the middle of summer.

\subsection{Field Sampling}

Zooplankton studies of the Northeastern Caspian were carried out in the spring (20-28 May) and summer (18-29 August) of 2010, and the Northern and Middle Caspian-in the spring (from 25 May to 2 June) and summer (15-26 August) of 2008 (Figure 1). Zooplankton samples were collected using the Juday net with the inlet diameter of $12 \mathrm{~cm}$ with the sieve-size of $64 \mu \mathrm{m}$, by double pulling it through from bottom to surface. In total, 82 samples of zooplankton were selected on the standard grid of stations, including 30 samples in the Northeastern Caspian, 26 in the Northern, and 26 in the Middle Caspian. The coordinates of the stations were determined using a GPS navigator; depth, transparency, $\mathrm{pH}$, temperature, and salinity of water by using a multi-parameter instrument HORIBA U-10.

\subsection{Laboratory Processing}

Zooplankton samples were processed by standard methods [42] using guides to species identification [43-45]. The quantitative (abundance, biomass) and structural variables (an average individual mass of a specimen [22], Shannon index values [46], $\Delta$-Shannon [23,25], Clarke's $\mathrm{W}$-statistic [33]) were determined to characterize the structure of zooplankton communities. An average individual mass of a specimen was calculated as the total biomass divided by the total abundance of zooplankton. The similarity of species composition of zooplankton communities was determined by the Sørensen index using the Primer 5 program. In the same program indexes of Shannon (Shannon Bi, bit/mg; Shannon $\mathrm{Ab}$, bit/specimen) and Clarke's W-statistics were calculated. The values of $\Delta$-Shannon were calculated as the arithmetic difference between the two versions of the Shannon index ( $\Delta$-Shannon $=$ Shannon Ab-Shannon Bi). Spearman's rank correlation values [47] between structural variables of zooplankton communities (Clarke's W-statistics, $\Delta$-Shannon, an average individual mass of a specimen, Shannon Bi) were calculated in Statistica 10, with $p<0.05$. For all parameters, the mean values with a standard error were calculated in Excel program. Seasonal differences in mean values of structural variables of zooplankton were determined for each region (Northeastern, Northern and 
Middle Caspian) according to Student's $t$-test. All biological variables were calculated separately for holoplankton (excluding jellyfish) and the zooplankton as a whole (including jellyfish).

\section{Results}

\subsection{Hydrophysical and Hydrochemical Characteristics of Study Sites}

During the research periods, the shallowest northeastern part of the water area had relatively low transparency of water (Table 1). As the depth increased towards the south, water transparency increased and reached a maximum in the Middle Caspian.

Table 1. Hydrophysical and hydrochemical characteristics of the studied water area of the Caspian Sea (mean with standard error).

\begin{tabular}{ccccccc}
\hline Water Area & Season, Year & Depth, $\mathbf{m}$ & Transparency, $\mathbf{m}$ & pH & Temperature, ${ }^{\circ} \mathbf{C}$ Salinity, $\%$ o \\
\hline \multirow{2}{*}{ Northeastern Caspian } & spring 2010 & $5.2 \pm 0.5$ & $1.5 \pm 0.1$ & $8.07 \pm 0.02$ & $21.7 \pm 0.2$ & $7.4 \pm 0.1$ \\
& summer 2010 & $5.3 \pm 0.4$ & $1.6 \pm 0.1$ & $7.92 \pm 0.08$ & $26.9 \pm 0.4$ & $8.4 \pm 0.2$ \\
\hline \multirow{2}{*}{ Northern Caspian } & spring 2008 & $7.1 \pm 1.0$ & $2.5 \pm 0.4$ & $8.94 \pm 0.07$ & $20.5 \pm 0.3$ & $7.2 \pm 0.9$ \\
& summer 2008 & $7.0 \pm 1.1$ & $2.8 \pm 0.7$ & $8.67 \pm 0.06$ & $23.4 \pm 0.2$ & $8.2 \pm 0.5$ \\
\hline \multirow{2}{*}{ Middle Caspian } & spring 2008 & $38.4 \pm 6.1$ & $10.6 \pm 0.9$ & $8.83 \pm 0.02$ & $18.3 \pm 1.2$ & $9.7 \pm 1.0$ \\
& summer 2008 & $34.9 \pm 7.0$ & $9.4 \pm 1.0$ & $8.71 \pm 0.09$ & $25.2 \pm 0.3$ & $11.4 \pm 0.2$ \\
\hline
\end{tabular}

In spring, an average water temperature varied from 18.3 to $21.7^{\circ} \mathrm{C}$, with a minimum in the deep-water Middle Caspian. In summer, the shallow areas of the Northeastern Caspian warmed up to the greatest extent. The water temperature of the deep-water Middle Caspian was only slightly lower than in the northeastern part of the water area, but statistically much higher than in the Northern Caspian. Throughout the surveyed area, the average salinity of water increased significantly from spring to summer, which is associated with a seasonal decrease in river flow.

\subsection{Species Richness}

A total of 37 taxa of zooplankton were identified in the surveyed water area of the Caspian Sea, with rotifers accounting for the greatest species richness (Table 2). From spring to summer, the number of species of planktonic invertebrates in the northeastern part of the water area did not change and decreased in the Northern and Middle Caspian.

Table 2. Species richness of zooplankton communities in the surveyed water area of the Caspian Sea.

\begin{tabular}{ccccccc}
\hline Water Area & Season, Year & Rotifera & Cladocera & Copepoda & Others & Total \\
\hline Northeastern Caspian & spring 2010 & 6 & 6 & 4 & 3 & 19 \\
Northeastern Caspian & summer 2010 & 5 & 4 & 4 & 6 & 19 \\
Northern Caspian & spring 2008 & 9 & 7 & 10 & 6 & 32 \\
Northern Caspian & summer 2008 & 8 & 3 & 4 & 6 & 21 \\
Middle Caspian & spring 2008 & 4 & 6 & 4 & 2 & 16 \\
Middle Caspian & summer 2008 & 3 & 3 & 1 & 4 & 11 \\
\hline Total & & 12 & 7 & 10 & 8 & 37 \\
\hline
\end{tabular}

Copepods Acartia tonsa Dana, Calanipeda aquedulcis Kritchagin, larvae of Bivalvia, Cirripedia, Hediste diversicolor (O.F. Müller) (Figure 2) were found during both seasons across the surveyed area. Rotifers Brachionus quadridentatus Hermann, Synchaeta stylata Wierzejski, cladocerans Cornigerius maeoticus hircus (Sars), Evadne anonyx Sars, Pleopis polyphemoides (Leuckart), Podonevadne angusta (Sars), Podonevadne camptonyx (Sars), Podonevadne trigona (Sars), and cyclops Halicyclops sarsi Akatova were widespread, predominantly in spring. Podon intermedius Lilljeborg was found only in the Middle Caspian. Jellyfish Blackfordia virginica Mayer and Moerisia pallasi (Derzhavin) were found in the 
zooplankton of the Northern Caspian during both seasons, of the Northeastern Caspian in summer, and in the deep-water Middle Caspian, there was none.

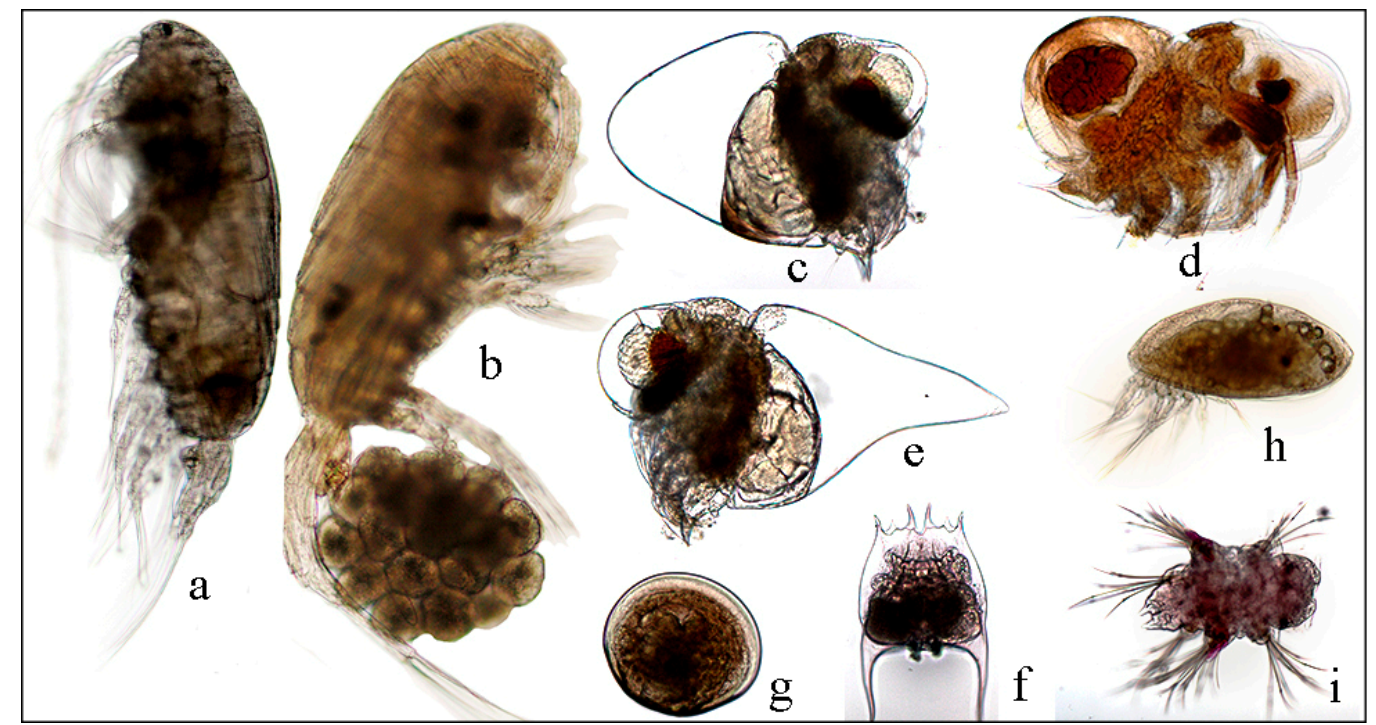

Figure 2. Photos of the dominant species in zooplankton communities in the surveyed waters of the Caspian Sea. Copepods: (a) Acartia tonsa, (b) Calanipeda aquedulcis; cladocerans: (c) Podonevadne trigona, (d) Podon intermedius, (e) Podonevadne camptonyx; rotifers: (f) Brachionus quadridentatus; others: (g) larvae of Bivalvia, (h) larvae of Cirripedia, (i) larvae of Hediste diversicolor.

According to the values of the Sørensen index, the zooplankton communities of all the examined regions of the Caspian Sea had a similar species composition in both seasons and years (Figure 3). The season had a greater influence on the species composition of planktonic invertebrates than the location of the surveyed areas. The zooplankton community of the Middle Caspian Sea in the summer period had the smallest species similarity with other water areas.

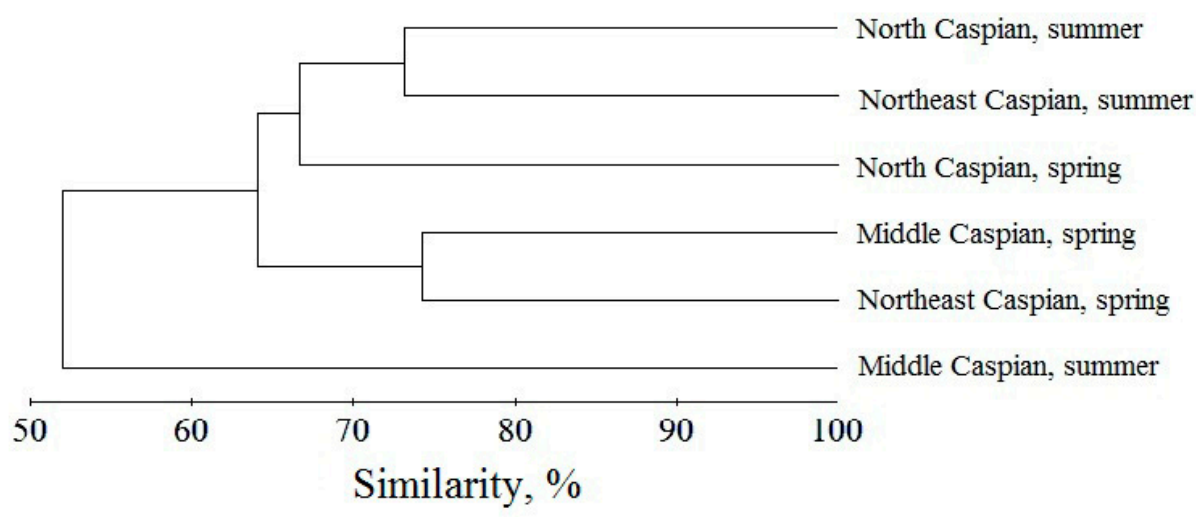

Figure 3. Dendrogram of the similarity of the species composition of zooplankton communities in the surveyed waters of the Caspian Sea.

\subsection{Quantitative Variables and Composition of the Dominant Species}

The greatest quantitative variables of zooplankton were recorded in the Northeastern Caspian in spring (Table 3). The total abundance of planktonic invertebrates decreased in the direction from the northeast to the south. From spring to summer, the number of zooplankton decreased in the Northern and Northeastern Caspian and remained practically unchanged in the Middle Caspian. During the studied period, the biomass of holoplankton of the Northeastern and Northern Caspian decreased, and the total biomass, on the contrary, increased due to the presence of large jellyfish in zooplankton. 
In the Middle Caspian, the holoplankton biomass was at a very low level. From spring to summer, the value of this variable increased by 1.7 times.

Table 3. Quantitative variables of zooplankton communities in the surveyed water area of the Caspian Sea (mean with standard error).

\begin{tabular}{|c|c|c|c|c|}
\hline Water Area & Season, Year & $\begin{array}{c}\text { Abundance, } \\
10^{3} \text { Specimen } / \mathrm{m}^{3}\end{array}$ & $\begin{array}{l}\text { Biomass of Holoplankton, } \\
\mathrm{mg} / \mathrm{m}^{3}\end{array}$ & $\begin{array}{l}\text { Biomass of Zooplankton } \\
\text { (with Jellyfish), } \mathrm{mg} / \mathrm{m}^{3}\end{array}$ \\
\hline \multirow{2}{*}{ Northeastern Caspian } & spring 2010 & $150.8 \pm 40.8$ & $690.2 \pm 119.0$ & no jellyfish \\
\hline & summer 2010 & $57.6 \pm 18.3$ & $245.1 \pm 60.8$ & $1278.5 \pm 351.4$ \\
\hline \multirow{2}{*}{ Northern Caspian } & spring 2008 & $60.2 \pm 20.1$ & $208.4 \pm 63.8$ & $488.6 \pm 294.5$ \\
\hline & summer 2008 & $14.2 \pm 3.1$ & $53.2 \pm 10.4$ & $1766.5 \pm 685.2$ \\
\hline Middle Caspian & spring 2008 & $3.8 \pm 0.7$ & $20.2 \pm 10.7$ & no jellyfish \\
\hline
\end{tabular}

The most significant contribution to quantitative variables of holoplankton was made by a few species (Table 4). Their composition remained relatively constant during both seasons, but the ratio of species in the quantitative variables of the community changed. Rotifers were numerous in the spring. In summer, copepods $A$. tonsa dominated by abundance and biomass. In spring, the composition of holoplankton species, dominating by biomass, was more diverse. In addition to $A$. tonsa, crustaceans C. aquedulcis, P. camptonyx, P. trigona, E. anonyx, and rotifers played a prominent role in the community.

Table 4. Composition of the dominant species in zooplankton communities in the surveyed water area of the Caspian Sea.

\begin{tabular}{|c|c|c|c|c|}
\hline \multirow{2}{*}{ Water Area } & \multirow{2}{*}{ Season, Year } & \multicolumn{3}{|c|}{ The Dominant Species } \\
\hline & & by Abundance (\%) & by Biomass without Jellyfish (\%) & by Biomass with Jellyfish (\%) \\
\hline \multirow[t]{2}{*}{$\begin{array}{l}\text { Northeastern } \\
\text { Caspian }\end{array}$} & spring 2010 & $\begin{array}{l}\text { Brachionus quadridentatus }(52.0) \\
\text { Calanipeda aquedulcis }(22.0) \\
\text { Acartia tonsa }(10.0)\end{array}$ & $\begin{array}{c}\text { Podonevadne camptonyx }(40.9) \\
\text { Calanipeda aquedulcis }(17.6) \\
\text { Podonevadne trigona }(12.7) \\
\text { Acartia tonsa }(9.5)\end{array}$ & no jellyfish \\
\hline & summer 2010 & $\begin{array}{c}\text { Acartia tonsa (34.9) } \\
\text { Brachionus quadridentatus (29.8) } \\
\text { Brachionus plicatilis (25.6) }\end{array}$ & $\begin{array}{l}\text { Acartia tonsa }(67.1) \\
\text { Calanipeda aquedulcis }(6.0) \\
\text { Brachionus plicatilis }(5.8)\end{array}$ & $\begin{array}{c}\text { Blackfordia virginica }(78.7) \\
\quad \text { Acartia tonsa }(12.9)\end{array}$ \\
\hline \multirow[t]{2}{*}{$\begin{array}{l}\text { Northern } \\
\text { Caspian }\end{array}$} & spring 2008 & $\begin{array}{c}\text { Brachionus quadridentatus (53.1) } \\
\text { Bivalvia gen. sp. }(13.7) \\
\text { Acartia tonsa }(7.8)\end{array}$ & $\begin{array}{c}\text { Asplanchna priodonta }(23.4) \\
\text { Brachionus quadridentatus }(14.0) \\
\text { Calanipeda aquae-dulcis }(13.7) \\
\text { Acartia tonsa }(12.4)\end{array}$ & $\begin{array}{l}\text { Blackfordia virginica }(57.4) \\
\text { Asplanchna priodonta }(10.0) \\
\text { Brachionus quadridentatus }(6.0) \\
\text { Calanipeda aquae-dulcis }(5.8)\end{array}$ \\
\hline & summer 2008 & $\begin{array}{c}\text { Acartia tonsa (49.7) } \\
\text { Brachionus plicatilis (13.6) } \\
\text { Brachionus quadridentatus (11.2) }\end{array}$ & $\begin{array}{c}\text { Acartia tonsa (53.4) } \\
\text { Podonevadne trigona (7.7) }\end{array}$ & Blackfordia virginica (96.7) \\
\hline \multirow[t]{2}{*}{$\begin{array}{l}\text { Middle } \\
\text { Caspian }\end{array}$} & spring 2008 & $\begin{array}{l}\text { Synchaeta cecilia (39.3) } \\
\text { Acartia tonsa (30.9) } \\
\text { Cirripedia gen. sp. (14.3) } \\
\text { Bivalvia gen. sp. (6.6) }\end{array}$ & $\begin{array}{l}\text { Acartia tonsa (54.4) } \\
\text { Evadne anonyx (14.3) }\end{array}$ & no jellyfish \\
\hline & summer 2008 & Acartia tonsa (93.8) & Acartia tonsa (92.2) & no jellyfish \\
\hline
\end{tabular}

Presence of jellyfish B. virginica and M. pallasi in the zooplankton of the Northeastern Caspian in the summer and the Northern Caspian in the spring and summer did not make a difference to the ratio of species by their abundance. Large sizes of individual jellyfish determined their dominant role in the total biomass of zooplankton, especially in the summer period (Table 4).

\subsection{Structural Variables}

The average number of species and values of the Shannon index in the Northeastern and Northern Caspian were higher than in the Middle Caspian (Table 5). When taking into account the few but large jellyfish, the Shannon $\mathrm{Ab}$ index values for the zooplankton of the Northeastern and Northern Caspian were slightly higher, and the Shannon Bi values were significantly lower than when calculating indices for holoplankton only. Holoplankton was characterized by small-sized composition that was confirmed by the low values of an average individual mass of a specimen. 
Table 5. Structural variables of zooplankton communities in the surveyed water area of the Caspian Sea (mean with standard error).

\begin{tabular}{|c|c|c|c|c|c|c|c|c|}
\hline \multirow[t]{2}{*}{ Water Area } & \multirow[t]{2}{*}{ Season, Year } & \multirow[t]{2}{*}{ Species Number } & \multicolumn{2}{|c|}{$\begin{array}{l}\text { * Shannon Ab } \\
\text { (bit/Specimen) }\end{array}$} & \multicolumn{2}{|c|}{$\begin{array}{c}\text { * Shannon Bi } \\
\text { (bit } / \mathrm{mg})\end{array}$} & \multicolumn{2}{|c|}{$\begin{array}{c}\text { * An average Individual Mass } \\
\text { of a Specimen (mg) }\end{array}$} \\
\hline & & & 1 & 2 & 1 & 2 & 1 & 2 \\
\hline \multirow{2}{*}{ Northeastern Caspian } & spring 2010 & $10.5 \pm 0.5$ & $1.95 \pm 0.12$ & no jellyfish & $2.20 \pm 0.09$ & no jellyfish & $0.0070 \pm 0.0013$ & no jellyfish \\
\hline & summer 2010 & $10.8 \pm 0.4$ & $1.55 \pm 0.13$ & $1.56 \pm 0.13$ & $1.54 \pm 0.19$ & $1.32 \pm 0.20$ & $0.0043 \pm 0.0011$ & $0.0399 \pm 0.0101$ \\
\hline \multirow{2}{*}{ Northern Caspian } & spring 2008 & $14.2 \pm 0.98$ & $1.85 \pm 0.17$ & $1.96 \pm 0.16$ & $2.35 \pm 0.15$ & $2.19 \pm 0.18$ & $0.0048 \pm 0.0008$ & $0.0071 \pm 0.0021$ \\
\hline & summer 2008 & $10.4 \pm 1.3$ & $1.74 \pm 0.18$ & $1.81 \pm 0.18$ & $1.67 \pm 0.20$ & $0.63 \pm 0.23$ & $0.0046 \pm 0.0007$ & $0.1980 \pm 0.0700$ \\
\hline Middle Caspian & spring 2008 & $8.3 \pm 0.6$ & $1.60 \pm 0.19$ & no jellyfish & $1.81 \pm 0.16$ & no jellyfish & $0.0122 \pm 0.0017$ & no jellyfish \\
\hline
\end{tabular}

Note: *1-holoplankton (without jellyfish), 2-zooplankton (with jellyfish). 
From spring to summer, the average number of species per sample (except for the Northeastern Caspian Sea), the values of Shannon Ab and Shannon Bi indices, and the average individual mass of a specimen in the zooplankton communities of the surveyed areas of the sea decreased.

For integrated characteristics of zooplankton structure, the values of the Clarke's W-statistics and $\Delta$-Shannon (Table 6) were calculated. As can be seen from Figure $4 a$, in the Northeastern and Northern Caspian, the Clarke's W-statistics and $\Delta$-Shannon increased from spring to summer; in the Middle Caspian, on the contrary, they decreased. When calculating the values of Clarke's W-statistics and $\Delta$-Shannon (Figure $4 \mathrm{~b}$ ), the abundance and biomass of jellyfish influenced only the absolute value, but not the nature of the seasonal dynamics of the variables.

Table 6. Values of Clarke's W-statistics of and $\Delta$-Shannon for zooplankton communities in the surveyed water area of the Caspian Sea (mean with standard error).

\begin{tabular}{cccccc}
\hline \multirow{2}{*}{ Water Area } & \multirow{2}{*}{ Season, Year } & \multicolumn{2}{c}{ Clarke's W-Statistics } & \multicolumn{2}{c}{$\Delta$-Shannon } \\
\cline { 3 - 6 } & & without Jellyfish & with Jellyfish & without Jellyfish & with Jellyfish \\
\hline \multirow{2}{*}{ Northeastern Caspian } & spring 2010 & $-0.050 \pm 0.033$ & no jellyfish & $-0.25 \pm 0.15$ & no jellyfish \\
& summer 2010 & $-0.017 \pm 0.021$ & $0.012 \pm 0.008$ & $-0.01 \pm 0.02$ & $-0.24 \pm 0.22$ \\
\hline \multirow{2}{*}{ Northern Caspian } & spring 2008 & $-0.068 \pm 0.029$ & $-0.038 \pm 0.030$ & $-0.42 \pm 0.18$ & $-0.24 \pm 0.20$ \\
& summer 2008 & $0.016 \pm 0.027$ & $0.178 \pm 0.050$ & $0.07 \pm 0.11$ & $1.18 \pm 0.28$ \\
\hline \multirow{2}{*}{ Middle Caspian } & spring 2008 & $-0.004 \pm 0.005$ & no jellyfish & $-0.21 \pm 0.14$ & no jellyfish \\
& summer 2008 & $-0.019 \pm 0.015$ & no jellyfish & $-0.08 \pm 0.07$ & no jellyfish \\
\hline
\end{tabular}
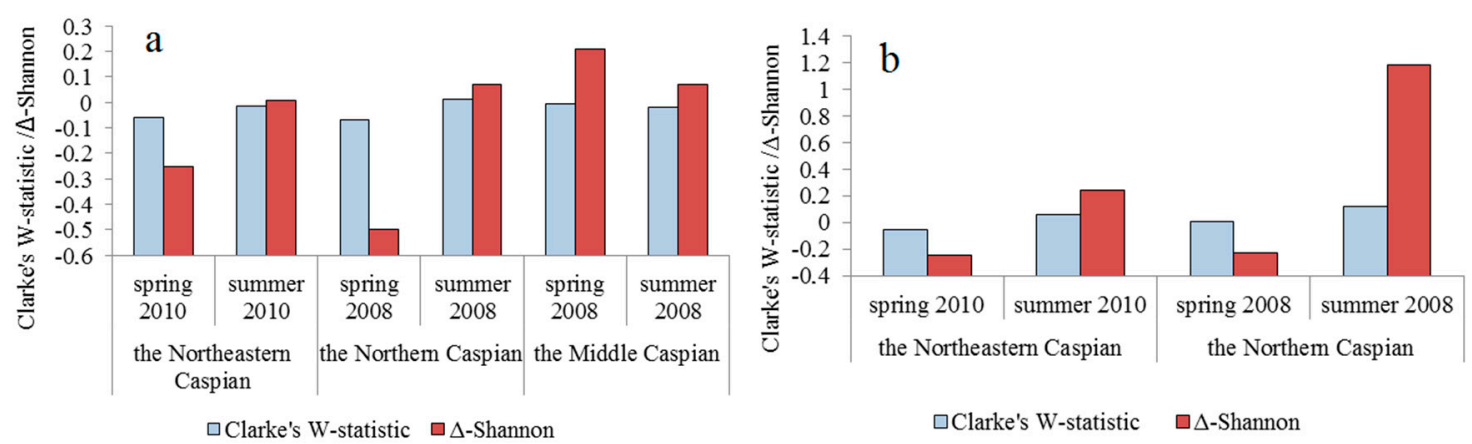

Figure 4. Seasonal changes in the values of Clarke's W-statistics and for holoplankton (a) and zooplankton (b) in the surveyed waters of the Caspian Sea.

According to Student's t-test (Table 7), seasonal changes of Shannon Bi were statistically significant for all surveyed areas of the sea. In the Northeastern Caspian, an average individual mass of a specimen (with jellyfish), values of Shannon $\mathrm{Ab}, \Delta$-Shannon, Clarke's W-statistics, and total biomass changes were statistically significant. In the Northern Caspian, seasonal changes of an average individual mass of a specimen (with jellyfish), total abundance and biomass (without jellyfish) were statistically significant. In the Middle Caspian values of Shannon $\mathrm{Ab}$, Shannon $\mathrm{Bi}$, and total biomass changes were statistically significant. 
Table 7. Evaluation of seasonal changes in the structure of zooplankton communities in the surveyed areas of the Caspian Sea according to Student's $t$-test, $p<0.05$.

\begin{tabular}{|c|c|c|c|c|c|}
\hline \multirow[t]{2}{*}{ Variables } & \multicolumn{2}{|c|}{$\begin{array}{c}\text { * Northeastern Caspian } \\
\text { (t-critical 2.14) }\end{array}$} & \multicolumn{2}{|c|}{$\begin{array}{l}* \text { Northern Caspian } \\
\text { (t-critical 2.16) }\end{array}$} & \multirow{2}{*}{$\begin{array}{c}\text { * Middle Caspian } \\
\text { (t-critical 2.16) }\end{array}$} \\
\hline & 1 & 2 & 1 & 2 & \\
\hline An average individual mass of a specimen, $\mathrm{mg}$ & -2.71 & 0.22 & -3.36 & 1.23 & 1.30 \\
\hline Shannon $\mathrm{Ab}$, bit/specimen & 0.58 & 12.30 & 1.79 & 1.83 & 4.67 \\
\hline Shannon Bi, bit/mg & 4.71 & 12.17 & 4.11 & 2.79 & 6.39 \\
\hline$\Delta$-Shannon & 3.80 & 1.40 & -0.03 & -1.25 & -0.53 \\
\hline Clarke's W-statistics & -3.00 & -1.00 & -1.30 & -0.44 & -0.40 \\
\hline Abundance, $10^{3}$ specimen $/ \mathrm{m}^{3}$ & 2.13 & 2.13 & 2.44 & 2.44 & 0.92 \\
\hline Biomass, $\mathrm{mg} / \mathrm{m}^{3}$ & -1.66 & 2.51 & -1.76 & 3.20 & 2.19 \\
\hline
\end{tabular}

Note: * 1-with jellyfish, 2-without jellyfish; statistically significant differences in averages are in italics.

Correlation analysis showed that the strong positive statistically significant links were recorded between the values of Clarke's W-statistics and $\Delta$-Shannon (Table 8). Positive statistically significant relationships were established between Clarke's W-statistics and an average individual mass of a specimen; negative connections were between Clarke's W-statistics and Shannon Bi, and between Shannon Bi and an average individual mass of a specimen.

Table 8. Spearman's rank correlation coefficients between structural variables of zooplankton communities in the surveyed water area of the Caspian Sea, $p<0.05$.

\begin{tabular}{|c|c|c|c|c|}
\hline \multirow{2}{*}{ Water Area } & \multirow{2}{*}{ Season, Year } & \multirow{2}{*}{ Paired Variables } & \multicolumn{2}{|c|}{ Spearman's Rank Correlation Coefficients } \\
\hline & & & without Jellyfish & with Jellyfish \\
\hline \multirow{8}{*}{ Northeastern Caspian } & \multirow{4}{*}{ spring 2010} & Clarke's W-statistics- $\Delta$-Shannon & 0.882 & \multirow{4}{*}{ no jellyfish } \\
\hline & & Clarke's W-statistics-m * & 0.72 & \\
\hline & & Clarke's W-statistics-Shannon Bi & -0.779 & \\
\hline & & Shannon Bi-m & - & \\
\hline & \multirow{4}{*}{ summer 2010} & Clarke's W-statistics- $\Delta$-Shannon & 0.964 & 0.979 \\
\hline & & Clarke's W-statistics-m & - & 0.732 \\
\hline & & Clarke's W-statistics-Shannon Bi & -0.780 & -0.946 \\
\hline & & Shannon $\mathrm{Bi}-\mathrm{m}$ & -0.571 & -0.846 \\
\hline \multirow{8}{*}{ Northern Caspian } & \multirow{4}{*}{ spring 2008} & Clarke's W-statistics- $\Delta$-Shannon & 0.864 & 0.9 \\
\hline & & Clarke's W-statistics-m & 0.7 & 0.645 \\
\hline & & Clarke's W-statistics-Shannon Bi & -0.691 & -0.718 \\
\hline & & Shannon $\mathrm{Bi}-\mathrm{m}$ & -0.700 & -0.745 \\
\hline & \multirow{4}{*}{ summer 2008} & Clarke's W-statistics- $\Delta$-Shannon & 0.955 & 0.827 \\
\hline & & Clarke's W-statistics-m & - & 0.772 \\
\hline & & Clarke's W-statistics-Shannon Bi & - & -0.782 \\
\hline & & Shannon $\mathrm{Bi}-\mathrm{m}$ & - & -0.964 \\
\hline \multirow{8}{*}{ Middle Caspian } & \multirow{4}{*}{ spring 2008} & Clarke's W-statistics- $\Delta$-Shannon & 0.951 & \multirow{4}{*}{ no jellyfish } \\
\hline & & Clarke's W-statistics-m & 0.797 & \\
\hline & & Clarke's W-statistics-Shannon Bi & - & \\
\hline & & Shannon $\mathrm{Bi}-\mathrm{m}$ & - & \\
\hline & \multirow{4}{*}{ summer 2008} & Clarke's W-statistics- $\Delta$-Shannon & 0.954 & \multirow{4}{*}{ no jellyfish } \\
\hline & & Clarke's W-statistics-m & - & \\
\hline & & Clarke's W-statistics-Shannon Bi & - & \\
\hline & & Shannon $\mathrm{Bi}-\mathrm{m}$ & - & \\
\hline
\end{tabular}

${ }^{*} \mathrm{~m}$-an average individual mass of a specimen.

\section{Discussion}

A total of 37 taxa were recorded in the zooplankton of the Northeastern, Northern, and Middle Caspian during spring and summer of 2008 and 2010. Zooplankton of the surveyed areas of the Sea was similar in species composition (Figure 3) in both seasons; however, the composition of the dominant species was different. Rotifers dominated in numbers mainly in spring, while in summer, crustaceans or jellyfish formed the main part of quantitative variables of zooplankton (Table 4). Invasive species Acartia tonsa and Calanipeda aquedulcis played a prominent role in the zooplankton of all surveyed areas of the sea. Both species are eurybiotic [48] and are found throughout the year in the Caspian Sea [49]. 
As in the Black Sea [50], in the Caspian Sea, the maximum numbers of A. tonsa and C. aquedulcis are characteristic of the summer-autumn period [49,51,52]. The population dynamics and age structure of these dominant species largely determined the spatial and seasonal changes in the quantitative and structural variables of the entire zooplankton of the Caspian Sea.

An average abundance of zooplankton ranged from 3.6 to 150.8 thous specimen $/ \mathrm{m}^{3}$. The biomass of holoplankton was equal to $20.2-690.2 \mathrm{mg} / \mathrm{m}^{3}$, and when taking into account the jellyfish Blackfordia virginica and Moerisia pallasi, reached $488.6-1766.5 \mathrm{mg} / \mathrm{m}^{3}$. The abundance of planktonic invertebrates in the shallow Northeastern Caspian, influenced by river runoff, was significantly higher than in the deep-water Middle Caspian (Table 3). As is known, the most favorable conditions for aquatic biota are formed in the estuaries of rivers, where the content of nutrients is higher than in deep water area [53]. According to our previous data [54], in spring 2008, the total content of nitrogen compounds in the Northern Caspian was higher than in the Middle Caspian (Table 9). The number of microalgae, predominantly consumed by planktonic invertebrates, was also higher in the Northern Caspian (373.9-415.9 mln.cell $\left./ \mathrm{m}^{3}\right)$ than in the Middle Caspian (28.0-47.9 mln.cell $\left./ \mathrm{m}^{3}\right)$ [55].

Table 9. Content of nutrients in the water of the Northern and Middle Caspian (by: [54]).

\begin{tabular}{ccccccc}
\hline \multirow{2}{*}{ Water Area } & \multirow{2}{*}{ Season, Year } & \multicolumn{5}{c}{ Content of Nutrients, $\mathbf{~} \mathbf{c} / \mathbf{d m}^{\mathbf{3}}$} \\
\cline { 3 - 7 } & & $\mathbf{N H}_{\mathbf{4}}{ }^{+}$ & $\mathbf{N O}_{2}{ }^{-}$ & $\mathbf{N O}_{3}{ }^{-}$ & Total of Nitrogen & PO $_{4}{ }^{-}$ \\
\hline \multirow{2}{*}{ Northern Caspian } & spring 2008 & 0.113 & 0.0016 & 0.135 & 0.250 & 0.004 \\
& summer 2008 & 0.091 & 0.0032 & 0.125 & 0.219 & 0.004 \\
\hline \multirow{2}{*}{ Middle Caspian } & spring 2008 & 0.091 & 0.0015 & 0.127 & 0.220 & 0.002 \\
& summer 2008 & 0.127 & 0.0019 & 0.128 & 0.257 & 0.004 \\
\hline
\end{tabular}

The average individual mass of a specimen (excluding jellyfish) in the surveyed water area of the Caspian Sea varied from 0.0043 to $0.0122 \mathrm{mg}$. According to the data of monitoring studies [14], low values of an average individual mass of a specimen $(0.0028-0.0072 \mathrm{mg})$ were characteristic of the zooplankton of the Northeast Caspian, with a downward trend in this indicator in the last decade. Such low values of an average individual mass of a specimen in zooplankton communities are recorded, as a rule, in eutrophic water bodies enriched with nutrients [22].

The values of the Shannon index decreased in the direction from the shallow Northeast Caspian to the southern deep-water areas, as well as from spring to summer in all surveyed areas of the sea (Table 5). The Shannon Bi index values were generally higher than the Shannon Ab values, i.e., the distribution of species by biomass was more even than the distribution by abundance. Accordingly, the $\Delta$-Shannon and Clark $W$-statistics values were negative. According to the available data $[22,25,29,55]$, the opposite situation was observed in undisturbed communities, i.e., Shannon Ab values were higher than Shannon Bi values. Thus, the obtained results indicated that the structure of zooplankton in the surveyed waters of the Caspian Sea was disturbed.

Correlation analysis showed that structural variables of zooplankton communities changed simultaneously in the Caspian Sea (Table 8). The values of Clarke's W-statistics and $\Delta$-Shannon were higher in communities that consisted of large sized species, as evidenced by the positive statistically significant relationships between Clarke's $\mathrm{W}$-statistics and an average individual mass of a specimen. The predominantly negative relationships between the Shannon Bi index and an average individual mass of a specimen indicated that zooplankton communities with small-sized species were more diverse than communities with large-sized species. These results were consistent with previously obtained data on negative relationships between an average individual mass of a specimen or an average cell volume and the diversity of phytoplankton communities [30] and zooplankton [25,26].

Correlation analysis showed that there is a statistically significant strong positive relationship between $\Delta$-Shannon and W-statistics of Clark (Table 8), which we recorded earlier in the study of plankton communities of various water bodies of Kazakhstan [23-26]. This close relationship is explained by the fact that the calculation of both variables is based on the same principles-the ratio 
of species in terms of abundance and biomass. Thus, both indices characterize the rank distribution of species in communities and can be used in environmental studies. It is crucial that information on the rank distribution of species can be obtained by directly comparing the values of Shannon $\mathrm{Ab}$ and Shannon Bi. These indexes are calculated easier, and therefore, they are used much more often $[22,56,57]$ than Clark's W-statistics $[58,59]$ when describing the structure of communities.

The $\Delta$-Shannon indices and Clark $\mathrm{W}$-statistics are closely related to dimensional variables and the diversity of communities. According to the results of the correlation analysis, the values of $\mathrm{W}$-statistics of Clark and $\Delta$-Shannon were higher in communities consisting of large species (Table 8). This was evidenced by the positive statistically significant relationships between the W-statistics of Clark and an average individual mass of a specimen. The predominantly negative relationship between the Shannon Bi Index and an average individual mass of a specimen indicated that zooplankton communities with small species were more diverse than communities with large species. These results corresponded to previously obtained data on the negative relationships between the size variables (an average individual mass of a specimen or an average cell volume) and the diversity of the communities of phytoplankton [30] and zooplankton [24-26].

Thus, the size variables and the rank distribution of species indicated a disturbance of the structure of the zooplankton communities of the Caspian Sea. Organic pollution of the Caspian Sea may be one of the reasons for this; but in terms of the total content of nitrogen and phosphorus, the water in the surveyed areas of the sea belonged to the first highest water quality class [60]. In terms of phytoplankton biomass (an average of $0.23-0.29 \mathrm{~g} / \mathrm{m}^{3}$ in the Middle Caspian and $0.65-0.66 \mathrm{~g} / \mathrm{m}^{3}$ in the Northern Caspian) [61], the water in these areas was slightly polluted and belonged to the second class of quality [60]. The values of an average individual mass of a specimen in the zooplankton communities of the Caspian surveyed waters corresponded to the level of eutrophic water bodies [22], with a high content of organic substances in the water. The inconsistency of water quality estimates is associated with the controlling influence of zooplankton on phytoplankton [62]; in turn, algae use nutrients, reducing their concentration in water [63]. These data indicate that water quality assessment should be carried out comprehensively, with the obligatory involvement of biological methods.

The seasonal dynamics of zooplankton in the surveyed areas of the sea had its distinguishing characteristics. In the Northeastern and Northern Caspian (Table 9), the total content of nitrogen compounds [54], the quantitative variables of phytoplankton [61] and holoplankton decreased from spring to summer, but the transparency of water (Table 1) and values of Clarke's W-statistics, on the contrary, increased. The seasonal dynamics of the above variables showed that the water quality in shallow areas of the sea improved from spring to summer. At the same time, the seasonal decrease in the average individual mass of a specimen testified to the deterioration of water quality [22] in shallow-water areas of the sea, i.e., contradicted changes in other structural variables. This contradiction could be associated with the pressure of predatory jellyfish Blackfordia virginica and Moerisia pallasi, feeding on planktonic invertebrates. Earlier, we showed a pronounced effect of jellyfish on all structural variables of holoplankton [14]. During our observations, the jellyfish pressure increased from spring to summer, which caused a decrease in the size parameters of holoplankton (Table 5), in contrast to the dynamics of other indicator variables.

In the Middle Caspian, where there were no jellyfish, all structural variables of zooplankton changed synchronically. Seasonal change in zooplankton structure (decrease in an average mass of a specimen and Clarke's W-statistics values, an increase in the holoplankton biomass) indicated strengthening of eutrophication processes and deterioration of water quality in this deep-sea area from spring to summer. This conclusion was confirmed by both a seasonal increase in the amount of nutrients (Table 9), a decrease in the transparency of the water (Table 1), and an increase in the abundance of phytoplankton [54]. The positive relationship between the seasonal dynamics of phytoplankton and the nutrient content was also established for the Baltic Sea $[64,65]$. Synchronous changes in the abundance of both plankton communities in the examined parts of the Caspian Sea indicated that 
zooplankton controlled the development of phytoplankton under the existing nutrient load. The role of zooplankton in phytoplankton biomass decline and water transparency regulation is shown in [19].

In general, the structural variables of zooplankton communities (decrease in size variables, negative values of $\mathrm{W}$-statistics of Clark and $\Delta$-Shannon) indicated an increase in the eutrophication processes of the Caspian Sea and deterioration of water quality. The eutrophication of the Northern Caspian Sea is associated with the increased inflow of organic matter since the 90s with the flow of the Volga and Ural rivers [9]. The hydrological regime of the inflowing rivers, mainly the Volga, also causes seasonal changes in the water quality of the Northern Caspian [15]. According to the results obtained, at present, not only the shallow water areas of the sea which are under the influence of river runoff are exposed to eutrophication, but also the deep-water areas of the Middle Caspian. From spring to summer water quality improved in the shallow northern and northeastern areas of the sea and it decreased in the deep-water Middle Caspian. These differences are due to the greater inertia of the deep-water Middle Caspian, compared with the shallow water zone. It manifested in a shift of the temperature maximum to a later date, reducing the average transparency of water, as well as in the dynamics of nutrients, whose content in the Middle Caspian Sea increased significantly from spring to summer.

\section{Conclusions}

Abundance, zooplankton biomass, an average individual mass of a specimen, Shannon Bi, Shannon $\mathrm{Ab}, \Delta$-Shannon, and Clark $\mathrm{W}$-statistics indices were applied to assess the quality of the water of the Caspian Sea. Quantitative variables of plankton communities decreased in the direction from the Northeastern and Northern Caspian to the Middle Caspian. Seasonal changes in biological variables in studied parts of the Caspian Sea were different. From spring to summer in the northeastern and northern parts of the Caspian Sea, the number of planktonic invertebrates, and the values of the Shannon Bi and Shannon Ab indices decreased; Shannon and Clark W-statistic values increased. In the deep-water Middle Caspian, the structural variables of zooplankton changed in the opposite direction: the biomass of the community increased; the values of $\Delta$-Shannon and Clarke's W-statistic decreased. From spring to summer, the value of an average individual mass of a specimen decreased throughout the entire study area. Jellyfish Blackfordia virginica and Moerisia pallasi had a significant impact on the dimensional structure of holoplankton. In general, seasonal and spatial changes in the structure of zooplankton corresponded to the dynamics of nutrients and microalgae. Seasonal dynamics of structural variables of zooplankton as well as changes in water transparency showed that water quality improved from spring to summer in the shallow northern and northeastern areas of the sea, and decreased in the deep-water Middle Caspian.

Funding: This research received no external funding.

Acknowledgments: The material was collected as part of implementing the following programs: "State environmental monitoring on the shelf and the coastal zone of the Caspian Sea using remote sensing" (Kazakhstan Agency of Applied Ecology LLP, Almaty, Kazakhstan) and "Study of the state of animal world of the Northeastern Caspian Sea under conditions of increased anthropogenic load" (Kazakhstan Ecological Project LLP, Almaty, Kazakhstan).

Conflicts of Interest: The funders had no role in the design of the study; in the collection, analyses, or interpretation of data; in the writing of the manuscript, or in the decision to publish the results.

\section{References}

1. Meier, M.H.E.; Müller-Karulis, B.; Andersson, H.C.; Dieterich, C.; Eilola, K.; Gustafsson, B.G.; Höglund, A.; Hordoir, R.; Kuznetsov, I.; Neumann, T.; et al. Impact of Climate Change on Ecological Quality Indicators and Biogeochemical Fluxes in the Baltic Sea: A Multi-Model Ensemble Study. Ambio 2012, 41, 558-573. [CrossRef] [PubMed] 
2. Brander, K.M.; Ottersen, G.; Bakker, J.P.; Beaugrand, G.; Herr, H.; Garthe, S.; Gilles, A.; Kenny, A.; Siebert, U.; Skjolda, H.R.; et al. Environmental Impacts-Marine Ecosystems. In North Sea Region Climate Change Assessment, Regional Climate Studies; Quante, M., Colijn, F., Eds.; Springer: Kongens Lyngby, Denmark, 2016; pp. 241-274.

3. Barber, D.G.; Asplin, M.G.; Papakyriakou, T.N.; Miller, L.; Else, B.G.T.; Iacozza, J.; Mundy, C.J.; Gosslin, M.; Asselin, N.C.; Ferguson, S.; et al. Consequences of change and variability in sea ice on marine ecosystem and biogeochemical processes during the 2007-2008. Canadian International Polar Year program. Clim. Chang. 2012, 115, 135-159. [CrossRef]

4. Holstein, A.; Kappas, M.; Propastin, P.; Renchin, T. Oil spill detection in the Kazakhstan sector of the Caspian Sea with the help of ENVISAT ASAR data. Environ. Earth Sci. 2018, 77, 198. [CrossRef]

5. Dolotov, Y.; Kaplin, P. Black and Caspian Seas. Coastal Ecology and Geomorphology. In Encyclopedia of Coastal Science; Schwartz, M.L., Ed.; Encyclopedia of Earth Science Series Springer: Dordrecht, The Netherlands, 2018; ISBN 978-1-4020-3880-8.

6. Karbassi, A.R.; Amirnezhad, R. Geochemistry of heavy metals and sedimentation rate in a bay adjacent to the Caspian Sea. Int. J. Environ. Sci. Technol. 2004, 1, 191. [CrossRef]

7. Qian, Y.; Zhang, W.; Yu, L.; Feng, H. Metal Pollution in Coastal Sediments. Curr. Pollut. Rep. 2015, 1, $203-219$. [CrossRef]

8. Korshenko, A.; Gul, A.G. Pollution of the Caspian Sea. In The Caspian Sea Environment. The Handbook of Environmental Chemistry; Kostianoy, A.G., Kosarev, A.N., Eds.; Springer: Berlin/Heidelberg, Germany, 2005; pp. 109-142.

9. Ivanov, V.P.; Sokolsky, A.F. Scientific Basis for the Strategy of Protecting the Biological Resources of the Caspian SEA from Oil Pollution; CaspNIRKH Publishing House: Astrakhan, Russia, 2000; 180p. (In Russian)

10. Huang, J.; Xie, Y.; Guan, X.; Li, D.; Ji, F. The dynamics of the warming hiatus over the Northern Hemisphere. Clim. Dyn. 2017, 48, 429-446. [CrossRef]

11. Sharmad, T.; Bidhendi, G.R.N.; Karbassi, A.R.; Moatar, F.; Adabi, M.H. Historical changes in distribution and partitioning of natural and anthropogenic shares of heavy metals in sediment core from the southern Caspian Sea. Environ. Earth Sci. 2012, 67, 799-811. [CrossRef]

12. Sobhanardakani, S.; Hosseini, S.V.; Miandare, H.K.; Faizbakhsh, R.; Harsij, M.; Regenstein, J.M. Determination of $\mathrm{Cd}, \mathrm{Cu}, \mathrm{Mn}$ and $\mathrm{Zn}$ concentrations in Iranian Caspian Sea caviar of Acipenser persicus using anodic stripping voltammetry. Iran J. Sci. Technol. Trans. Sci. 2017, 41, 139. [CrossRef]

13. Guseinova, S.A.; Abdusamadov, A.S. Forecast of the Caspian Sea level and its implications for coastal areas. South Russ. Ecol. Dev. 2015, 10, 119-126. [CrossRef]

14. Ecological Monitoring Studies of the Environment of the North-Eastern Caspian During the Development of Oil Fields of NCOC N.V; in the period from 2006 to 2016; Skolsky, V.A. (Ed.) North Caspian Operating Company N.V., Kazakh Agency of Applied Ecology: Almaty, Kazakhstan, 2018; 400p, ISBN 978-601-332-146-2. (In Russian)

15. Pollutants in the Waters of the Volga-Caspian Basin; Brekhovskikh, V.F.; Ostrovskaya, E.V. (Eds.) Publisher IP Sorokin Roman Vasilyevich: Astrakhan, Russia, 2017; 408p, ISBN 978-5-91910-527-5.

16. Adams, S.M.; Greeley, M.S. Multi-response indicators to assess the health of aquatic ecosystems. Water Air Soil Pollut. 2000, 123, 103-115. [CrossRef]

17. El-Kassas, H.Y.; Gharib, S.M. Phytoplankton abundance and structure as indicator of water quality in the drainage system of the Burullus Lagoon, southern Mediterranean coast. Egypt Environ. Monit. Assess. 2016, 188, 530. [CrossRef] [PubMed]

18. Barinova, S.S.; Medvedeva, L.A.; Kondratieva, L.M.; Shesterkin, V.P. Bio-indication in the Amur River, Russian Far East. Res. J. Pharm. Biol. Chem. Sci. 2015, 6, 1171-1187.

19. Gerasimova, T.N.; Pogozhev, P.I. The role of zooplankton in phytoplankton biomass decline and water transparency regulation in a water body subject to high organic and mineral load. Water Res. 2010, 37, 796-806. [CrossRef]

20. Filho, S.L.N.; França, E.J.; Júnior, M.M.; Moura, A.N. Interactions between benthic microalgae, nutrients and benthic macroinvertebrates in reservoirs from the semi-arid Neotropical region. Fundam. Appl. Limnol. 2019, 192, 237-254. [CrossRef]

21. Barinova, S. Algal Diversity Dynamics, Ecological Assessment, and Monitoring in the River Ecosystems of the Eastern Mediterranean; Nova Science Publishers: New York, NY, USA, 2011. 
22. Andronikova, I.N. Zooplankton Structural and Functional Organization of Lacustrine Ecosystems of Different Trophic Types; Nauka: St. Petersburg, Russia, 1996; 189p, ISBN 5-02-026713-9. (In Russian)

23. Krupa, E.G.; Barinova, S.S. Environmental Variables Regulating the Phytoplankton Structure in High Mountain Lakes. Res. J. Pharm. Biol. Chem. Sci. 2016, 7, 1251-1261.

24. Barinova, S.; Krupa, E. Bioindication of ecological state and water quality by phytoplankton in the Shardara Reservoir, Kazakhstan. Environ. Ecol. Res. 2017, 5, 73-92. [CrossRef]

25. Krupa, E.G.; Barinova, S.M.; Romanova, S.M.; Malybekov, A.B. Hydrobiological assessment of the high mountain Kolsay Lakes (Kungey Alatau, Southeastern Kazakhstan) ecosystems in climatic gradient. Br. J. Environ. Clim. Chang. 2016, 6, 259-278. [CrossRef]

26. Krupa, E.G.; Barinova, S.S.; Assylbekova, S.Z.; Isbekov, K.B. Structural indicators of zooplankton of the Shardara Reservoir (Kazakhstan) and the main influencing factors. Turk. J. Fish. Aquat. Sci. 2018, 18, 659-669. [CrossRef]

27. Alimov, A.F.; Golubkov, M.S. Lake Eutrophication and Community Structure. Inl. Water Biol. 2014, 3, 185-191. [CrossRef]

28. Ochocka, A.; Pasztaleniec, A. Sensitivity of plankton indices to lake trophic conditions. Environ. Monit. Assess. 2016, 188, 622. [CrossRef]

29. Krupa, E.G.; Barinova, S.S.; Romanova, S.M. Zooplankton size structure in the Kolsay mountain lakes (Kungei Alatau, southeastern Kazakhstan) and its relationships with environmental factors. Water Res. 2019, 46, 403-414. [CrossRef]

30. Klymiuk, V.; Barinova, S. Phytoplankton cell size in saline lakes. Res. J. Pharm. Biol. Chem. Sci. 2016, 7, 1077-1085.

31. Barinova, S.; Bilous, O.; Ivanova, N. New statistical approach to spatial analysis of ecosystem of the Sasyk Reservoir, Ukraine. Int. J. Ecotoxicol. Ecobiol. 2016, 1, 118-126. [CrossRef]

32. Warwick, R.M. A new method for detecting pollution effects on marine macrobenthos communities. Marine Biol. 1986, 92, 557-562. [CrossRef]

33. Clarke, K.R. Comparison of dominance curves. J. Exp. Mar. Biol. Ecol. 1990, 138, 143-157. [CrossRef]

34. Krupa, E.G. The size structure of zooplankton as an indicator of the ecological status of the Caspian Sea. In Marine Biological Studies: Achievements and Prospects, Proceedings of the Materials of the All-Russian Conference, Sevastopol, Russian, 2016; ECOSY-Hydrophysics: Sevastopol, Russia, 2016; Volume 3, pp. 119-123. (In Russian)

35. Krupa, E.G.; Barinova, S.M. The use of structural indicators of hydrocenoses in assessing the ecological status of water bodies in Kazakhstan. In Bioindication in Monitoring Freshwater Ecosystems: The Third International Conference; Institute of Lake Science of RAS: St. Petersburg, Russia, 2017; pp. 165-170.

36. Krupa, E.G.; Grishaeva, O.V. The structure of species dominance in the macrozoobenthos of the Small Aral Sea as an indicator of changes in water salinity. In Bioindication in Monitoring Freshwater Ecosystems: Abstracts of the Second International Conference; Lyubavich: St. Petersburg, Russia, 2011; p. 96.

37. Diamant, A.; Westernhagen, H. MARS: Biological indicators of natural and man-made changes in marine and coastal waters: Scientific coordinators introduction. Helgol. Marine Res. 2003, 57, 146-156. [CrossRef]

38. Barinova, S.; Bondarenko, A.; Ryabushko, L.; Kapranov, S. Microphytobenthos as an indicator of water quality and organic pollution in the western coastal zone of the Sea of Azov. Oceanol. Hydrobiol. Stud. 2019, 48, 21-35. [CrossRef]

39. Parizanganeh, A.; Lakhan, V.C.; Jalalian, H.A. Geochemical and statistical approach for assessing heavy metal pollution in sediments from the southern Caspian coast. Int. J. Environ. Sci. Technol. 2007, 4, 351-358. [CrossRef]

40. Monitoring of the Environment of the Northeastern Caspian Sea When Developing Oil Deposits (Results of Agip KCO Studies, 1993-2006); Ogar, N.P. (Ed.) Agip KCO: Almaty, Kazakhstan, 2014; 263p, ISBN 5-02-033731-5. (In Russian)

41. Caspian Sea. Hydrology and Hydrochemistry; Baydin, S.S., Kosareva, A.N., Eds.; Science: Moscow, Russia, 1986; 261p. (In Russian)

42. Zooplankton and Its Products. Guidelines for the Collection and Processing of Materials in Hydrobiological Research in Freshwater Water Bodies; Winberg, G.G., Lavrenteva, G.M., Eds.; GosNIIORH: Leningrad, Russia, 1984; 34p. (In Russian) 
43. Borutsky, E.V.; Stepanova, L.A.; Koss, M.S. Determinant for Calanoida in Fresh Waters of the USSR; Science: St. Petersburg, Russia, 1991; 504p. (In Russian)

44. Kutikova, L.A. Rotifer in USSR Fauna; Science: Leningrad, Russia, 1970; 744p. (In Russian)

45. Key to Freshwater Invertebrates of Russia and Adjacent Lands; Tsalolihin, S.Y. (Ed.) Zoological Institute: St. Petersburg, Russia, 1995; 628p. (In Russian)

46. Magurran, E. Ecological Diversity and its Measurement; Mir: Moscow, Russia, 1998; 184p, ISBN 5-03-002404-2. (In Russian)

47. Glantz, S.A. Primer of BIOSTATISTICS; Praktik: Moscow, Russia, 1998; 459p, ISBN 5-89816-009-4. (In Russian)

48. Krupa, E.G.; Dobrokhotova, O.V.; Stuge, T.S. Fauna Calanoida (Crustacea, Copepoda) of Kazakhstan and Adjacent Territories; EtalonPrint: Almaty, Kazakhstan, 2016; 208p, ISBN 978-601-80265-8-4. (In Russian)

49. Krupa, E.; Kokhno, L.; Kiyko, O. Zooplankton. In Environmental Monitoring Studies of the Environment of the Northeast Caspian Sea During the Development of Oil Fields by NCOC N.V. in the Period from 2006 to 2016; Skolsky, V.A., Ed.; North Caspian Operating Company N.V., Kazakh Agency of Applied Ecology: Almaty, Kazakhstan, 2018; pp. 139-159. ISBN 978-601-332-146-2. (In Russian)

50. Shadrin, N. Acartia tonsa (Copepoda) in the Black and Caspian Seas: Review and some lessons. J. Biodiv. 2013, 22, 229-236. [CrossRef]

51. Kurasheva, E.K.; Tinenkova, D.K.H. Population abundance, biomass and distribution of Acartia clausi Gisbrecht (Calanoida, Acartiidae) in the North and Middle Caspian. Hydrobiol. J. 1988, 24, 23-27. (In Russian)

52. Krupa, E.G.; Sagandykova, R.R.; Klimov, F.V. Characteristics of zooplankton of the northeastern part of the Caspian Sea in a seasonal aspect. In Some Aspects of Hydroecological Problems of Kazakhstan; Burlibaev, M., Ed.; Kaganat: Almaty, Kazakhstan, 2011; pp. 127-134. ISBN 978-601-78-596-8. (In Russian)

53. Leonov, A.V.; Nazarov, N.A. Nutrient input into the Caspian Sea with river runoff. Water Res. 2001, 28, 656-665. [CrossRef]

54. Krupa, E.G.; Orlova, I.V. Structure of zooplankton in the Kazakhstan sector of the northern and middle Caspian. In Some Aspects of the Hydroecological Problems of Kazakhstan; Burlibaev, M., Ed.; Kaganat: Almaty, Kazakhstan, 2011; pp. 120-126. ISBN 978-601-78-596-8. (In Russian)

55. Krupa, E.G. Zooplankton of Limnic and Lotic Ecosystems of Kazakhstan. Structure, patterns of formation-Saarbrucken; Palmarium Academic Publishing: Saarbrucken, Germany, 2012; 346p.

56. Kuczyńska-Kippen, N.; Joniak, T. Zooplankton diversity and macrophyte biometry in shallow water bodies of various trophic state. Hydrobiologia 2016, 774, 39-51. [CrossRef]

57. Thakar, M.K.; Luthra, D.; Khattar, J.S. Forensic studies of phytoplankton ecology of two water bodies of Kurukshetra area of Haryana, State in India. Egypt. J. Forensic Sci. 2018, 8, 38. [CrossRef]

58. Meire, P.M.; Dereu, J. Use of the Abundance/Biomass Comparison Method for detecting environmental stress: Some considerations based on intertidal macrozoobenthos and bird communities. J. Appl. Ecol. 1990, 27, 210-223. [CrossRef]

59. Shitikov, V.K.; Golovatyuk, L.V. ABC-method and specificity of species dominance in bottom river communities. Volga Ecol. J. 2013, 1, 88-97. (In Russian)

60. Barinova, S. On the classification of water quality from an ecological point of view. Int. J. Environ. Sci. Nat. Res. 2017, 2, 1-8. [CrossRef]

61. Krupa, E.G.; Mademarova, N.A. Structure of the phytoplankton of the Northern and Middle Caspian. News Nat. Acad. Sci. Republ. Kaz. 2016, 1, 70-77. (In Russian)

62. Gasiūnaitè, Z.R.; Olenina, I. Zooplankton-phytoplankton interactions: A possible explanation of the seasonal succession in the Kuršiu Marios lagoon. Hydrobiologia 1998, 363, 333-339. [CrossRef]

63. Moschonas, G.; Gowen, R.J.; Paterson, R.F.; Mitchell, E.; Stewart, B.M.; McNeill, S.; Glibert, P.M.; Davidson, K. Nitrogen dynamics and phytoplankton community structure: The role of organic nutrients. Biogeochemistry 2017, 134, 125-145. [CrossRef]

64. Dmitrieva, O.A.; Semenova, A.S. Seasonal dynamics of phyto- and zooplankton and their relationships in hypertrophic reservoir. Inl. Water Biol. 2011, 4, 308-315. [CrossRef]

65. Dmitrieva, O.A.; Semenova, A.S. Seasonal dynamics and trophic relationships of phyto- and zooplankton in the Vistula Lagoon of the Baltic Sea. Oceanology 2012, 52, 851-856. (In Russian) [CrossRef] 
(C) 2019 by the author. Licensee MDPI, Basel, Switzerland. This article is an open access article distributed under the terms and conditions of the Creative Commons Attribution (CC BY) license (http://creativecommons.org/licenses/by/4.0/). 